\title{
The Meaning of the Veneration of Nasi Jimat
}

Oda I. B. Hariyanto (Corresponding author)

Faculty of Arts, Universitas Padjadjaran

Bandung, Indonesia

E-mail: mariaoda26@yahoo.com

Prof. Dr. H. A. Sobana Hardjasaputra, MA (Promotor)

Dr. Dade Mahzuni (Promotor)

Nani Darmayanti, Ph.D (Promotor)

Received: January 21, 2015 Accepted: January 26, 2015 Published: February 4, 2015

doi:10.5296/ijch.v2i1.6986 URL: http://dx.doi.org/10.5296/ijch.v2i1.6986

\begin{abstract}
This research entitled "The Meaning of The Veneration of Nasi Jimat at Kasepuhan Palace Cirebon" examines nasi jimat (literally meaning amulet rice) in the ritual of Panjang Jimat (festival of noble amulet) as a cultural phenomenon. Nasi jimat is the main dish cooked and served in the ritual of Panjang Jimat. Nasi jimat is treated in a particular manner and is the center of attention among other dishes served in the ritual. Attending the festival and having even a pinch of nasi jimat is believed to have sacred merit and benefit by Cirebon people in general.
\end{abstract}

This research employs qualitative approach because the ritual of preparing nasi jimat is a complex and dynamic social phenomenon that holds cultural meaning. Therefore, the ritual of preparing nasi jimat is viewed as a cultural signifier. Semiotics approach is employed here to interpret the signs and symbols and to analyze the meaning.

The purpose of this research is to grasp the picture of the social situation and to analyze the notion underlying the veneration of nasi jimat as local wisdom of Cirebon people. The primary data are collected by conducting participative observation and in-depth interviews. The secondary data are gathered through a literature review to support the primary data. Triangulation is then used to increase the credibility and validity of all the data.

The result of the research shows that: 1) the tradition of preparing nasi jimat is a part of the 
Panjang Jimat ritual that takes place every year to preserve Cirebon traditional heritage; 2) Cirebon people in general consider attending the festival and having nasi jimat a momentous event; 3) They believe that participating in the veneration of nasi jimat would grant them (divine) blessing.

Keywords: Tradition, Veneration, Meaning, Nasi Jimat

\section{Introduction}

Various ethnic groups that spread over the 34 provinces of Indonesia have rich and diverse cultural heritage. Diversity in race, geographic origin, historical background, regional development, religion and belief, and traditional arts are part of the ethnic cultural richness, including their food and food customs. Rice is the staple food for the majority of Indonesian people. Ethnics groups in Indonesia have different ways of preparing rice based on the needs and purposes, with their own names unique to particular regions.

Different ethnic groups give different names to rice dishes on account of its different ways of cooking, different styles of serving, and the addition of various different extra ingredients (spices and condiments). For example, nasi kuning (yellow rice), nasi uduk (literally meaning mixed rice), nasi tumpeng (a cone-shaped rice dish), are usually served in special occasions such as slametan, a communal feast symbolizing the social unity of those participating in it, rich in values of local wisdom. Nasi kuning, nasi uduk, and nasi tumpeng, however, are also usually served for breakfast.

At Kasepuhan's palace (keraton) Cirebon, every year a ritual called panjang jimat takes place, where nasi jimat, nasi kebuli, along with various traditional side dishes, are served in the commemoration of Prophet Muhammad's birth. During the process of cooking nasi jimat, even before and after, prayers are continuously chanted. The process of preparing nasi jimat is a sacred ritual in itself since it imposes prerequisites and prohibitions for those who take part in the duty. For a tradition that has been practiced for more than five centuries, it is believed that violations against the tradition will not only spoil the dish, but also bring misfortune.

Such cultural phenomenon can only be found in societies or communities that adhere to the traditions of their ancestors, like what annually takes place at Kasepuhan palace Cirebon in the commemoration of Prophet Muhammad's birth. The tradition has been preserved and performed as a way to pay respect to the ancestors, thereby getting blessing from God. Nasi jimat is the main dish served in the ritual of panjang jimat and venerated particularly by the royal family of the palace and the people of Cirebon in general. When the ritual of preparing nasi jimat takes places, behind the wall of the palace, people have been waiting in line since early in the morning to have some nasi jimat and a few drops of minyak jimat (used cooking oil) to take home, which they believe could give them blessing and healing. The sacred ritual of preparing nasi jimat consists of the following sequence of activities: 1) recitation of a prayer prior to the process of cooking; 2) a prayer and special treatment during the process of cooking; 3) prerequisites for the cooks taking part in the ritual of preparing nasi jimat; 4) nasi jimat as one of the dishes served in the tradition of panjang jimat ritual. 
This research aims at describing systematically, factually and accurately the facts surrounding the process of preparing nasi jimat. The method employed in this research is descriptive qualitative case study since the meaning of the veneration of the ritual at Kasepuhan palace is a complex and dynamic cultural issue (Ratna, 2010). The data is collected through direct interaction by conducting in-depth interviews within a natural situation and condition during the ritual of preparing nasi jimat that takes place in dapur mulud (the kitchen) (Sugiyono, 2011), so that the data would fit the purpose of the research, supported by a literature review.

Based on the reasons mentioned above, the research on the veneration of nasi jimat at Kasepuhan palace Cirebon aims at 1) describing the traditional ritual of preparing nasi jimat; 2) preserving the tradition and local wisdom embodied in it; 3) explaining the meaning and the significance of the veneration of nasi jimat.

\section{Discussion}

\subsection{Kasepuhan Palace Cirebon}

Location and Borderlines: Kasepuhan Palace is located at Jl. Keraton Kasepuhan No. 43, Mandalangan village in the administrative area of Kasepuhan, district Lemahwungkuk. The name Kasepuhan is better known by the people of Cirebon as the palace (keraton), which was built in the 15th century, while Kasepuhan village is a division of Lemahwungkuk village. The borderlines of Kasepuhan Palace: to the northern part of the palace is the Kasepuhan street, and the Kriyan River to the south. To the west is residential area, and the eastern part is Mayor Sastraatmadja street.

Kasepuhan Palace is located in the coastal area of Cirebon. The palace was built by Prince Walangsungsang, who is better known by the name of Prince Cakrabuana. He founded Pakungwati kingdom, whose name was based on his daughter's name. Then, Prince Cakrabuana gave his throne to Syarif Hidayattulah, who was his son-in-law and also his nephew. Just as Prince Cakrabuana, Syarif Hidayatullah played an important role in the development of Islamic teaching and its dissemination in Cirebon. Sharif Hidayattulah became one of the walisongo (literally meaning nine saints) known as Sunan Gunung Jati. By handing over the kingdom of Pakungwati to Syarif Hidayattulah, it was the first step in building an Islamic kingdom in Sundanese land. Sunan Gunung Jati's wisdom in teaching and developing Islam in Cirebon followed the honorable ancestral traditions. Until now the traditions have survived, one of which is the tradition of preparing nasi jimat as a part of the ritual of panjang jimat. The tradition of panjang jimat is the peak of the event in the commemoration of Prophet Muhammad's birth, or it is also called Muludan in Cirebon language.

\subsection{The Meaning of the Veneration of Nasi Jimat}

\subsubsection{The Tradition of Preparing Nasi Jimat}

The tradition of preparing nasi jimat is a part of the panjang jimat ritual. The tradition of preparing nasi jimat has become a habit practiced continuously in the same manner by the royal family of Kasepuhan palace, together with a group of selected people taking part in the duty. The people of Cirebon attend the festival to watch the ritual of preparing nasi jimat (folkways). 
This is in accordance with Soekanto Soekamto's statement about a habit practiced in a long period of time and in the same manner by a group of people or a society (folkways), such as rules of social life; courtesy, decency, as well as ceremonies (Soekanto, 1990). The ritual of preparing nasi jimat has been performed by one generation to the next for five centuries since the time of Syarif Hidayatullah was the sultan (1478) of Kasepuhan palace Cirebon.

Nasi jimat is basically rice cooked using oil instead of water and it is treated in a special manner. The dish actually goes by of two different names. The first name is nasi minyak (oil rice) and the other name is nasi jimat (amulet rice), but nasi jimat is the more popular among people in general.

Based on the interview with the key source of the community, it is explained that: First, it is called nasi minyak (oil rice) or nasi jimat because it is cooked using oil, instead of water. Second, people usually call it nasi jimat because during process of cooking the dish, prayers are chanted by a kyai (spiritual leader) and by the women taking part in the duty. Other people who watch the process of preparing nasi jimat also join in the recitation of the prayers. Those who watch the ritual from behind the wall of the palace share the same sacred atmosphere.

So, there are two names for the same product: nasi minyak or nasi jimat. The word jimat (literally meaning talisman) is deeply attached and rooted in the minds of the people as something that has the power of blessing or healing. Therefore, having some nasi jimat and some minyak jimat (used oil from cooking the rice, put in a special container) to take home is believed to have sacred merit and benefit for them. They are willing to wait patiently since early in the morning to get even a pinch of nasi jimat and a few drops of minyak jimat.

As a matter of fact, the name nasi jimat actually refers to the main dish (the rice) and all the side dishes and fruits. Accompanied by the recitation of shalawat (pray for Prophet Muhammad), the dishes are then prepared in the chamber of Panembahan before being distributed. Then, nasi jimat is carried entering the rengrengan (procession) formation to be taken into langgar agung (mosque). At langgar agung, a recitation of al-Barzanji book, which tells the story of Prophet Muhammad's life, is then conducted. After the recitation, the feast begins with all the dishes served in meron and dondang (plates). Nasi jimat is distributed to each kyai who represent each of their followers. This tradition is different with grebeg maulud at Jogyakarta palace, where a gunungan (a huge pile of various kinds of food and snacks) are carried outside the palace where people have scrambled, ready to grab them.

\subsubsection{Preparation and Conditions in Preparing Nasi Jimat}

The preparations for cooking nasi jimat are as follows: (1) the ingredients consists of rice, coconut oil and coconut milk that has been boiled along with other seasonings. (2) A stove whose holder is made out of banana tree trunk; (3) the ritual preparation led by a kyai. Exactly at 06.00 in the morning, at the beginning of the ritual, as at the beginning of many ceremonial occasions, a prayer is led by the kyai for the success of the event. They pray for the blessing of the ritual.

The prerequisite to take part in the duty of preparing nasi jimat is that those who are involved must be women who have reached menopause period and there must be at least seven of them; 
a) four women stir up the rice using a long centong (traditional rice spoon), circiling around in a clockwise direction, b) one woman fans the smoke away so that it would not obscure the view, c) another woman clean up the karon (rice crust) from a kuali (huge pot) and make sure the crust do not fall off from the stove, d) an old woman sit in the corner, praying while watching the process of cooking. Those who perform the honorable duty in the kitchen are served with coffee and tamarind water.

\subsubsection{The Process of Cooking Nasi Jimat}

The process begins by setting up the oil in a large pot made of copper. Exactly at 06.00 the ritual begins and the prayer is chanted. The oil is heated up on the stove below the smoke point up to 70-80 degrees. Then, 30 kilograms of rice that have been washed and drained are poured into the pot already filled with heated oil. The temperature of the oil should be kept below the smoke point, 70-80 degrees $\mathrm{C}$, because when the heat reaches the smoke point, it would be the same as steaming the rice, which will spoil the dish. During the process of cooking, the rice should be stirred up using a long centong by four women who circle around the pot in a clockwise direction to make sure the rice is cooked evenly and to prevent the rice from getting burnt in the bottom of the pot.

To keep the temperature stable, the fire in the stove should be kept stable as well. A woman is tasked to fan the firewood using woven bamboo fan in order to: 1) keep the temperature stable around the cooking place, 2) to fan away the smoke from firewood that might obscure the view of the other women who circle around the pot, stirring up the rice. 3) Besides, it keeps the air fresh for the other women taking part in cooking nasi jimat. The ngaron (cooking rice) process takes about six hours in order for the rice to turn yellowish. Once the rice turns yellowish, the rice is then separated from the oil, and the oil is stored in a special container. This oil is called minyak jimat.

A woman is tasked to make sure that the karon (rice crust) do not fall from the pot. If the rice crust left on the side of the pot, then over time the rice will be scorched, and therefore they should always be cleaned, putting them back into the frying pan using a bunch of banana leaves used as a brush. In the corner of the room, an old woman sits on a jojodog (short chair), watching the process while chanting prayers.

Once the rice has turned yellowish, the rice is separated from the oil to be poured with coconut milk that has been mixed with spices. Once the coconut milk has seeped into the rice, the rice is then put into another pot covered with banana leaves in the bottom. Some banana leaves are put on the top along with the spices used from cooking the milk coconut. Then the large pot is closed tightly and the rice is cooked in a low temperature. It takes six hours to cook nasi jimat until it's done. One third of the rice is shared into seven containers called boboko for the ritual. Another one third is served for the royal family and the guests of the palace, while another one third, along with the used cooking oil, is distributed to the people who have been waiting in line in the front of dapur mulud (kitchen) since early in the morning.

The women who take part in the duty are served with beverages such as coffee to keep them bright-eyed and tamarind water mixed with brown sugar to keep them fresh and rejuvenated 
through the whole process of preparing nasi jimat. The whole preparation for the ritual of panjang jimat takes three days in a row until the day of the festival, which means they have to work overnight. Working in the kitchen night and day with all the smoke from the stove, drowsiness is hardly inevitable. To keep them fresh and awake, they are given coffee and tamarind water mixed with brown sugar. The functions of the tamarind water are: a) to provide energy for the body as it contains vitamin $\mathrm{C}, \mathrm{b}$ ) rejuvenate the body and relieve hunger, c) the brown sugar mixed with the tamarind water add calories for the body and it is very good for health.

\subsubsection{The Meaning of the Veneration of Nasi Jimat}

According to Danesi, meaning is a message and the way it is delivered through signs. A message can be delivered through many ways, one of which is through signs, and a sign are anything that represent another thing. It could be an object like a flower or, in this case, food (2006). Basically, a sign is related with the intentions of the messages. The meaning lying behind is a puzzling social expression, which requires interpretative analysis.

As mentioned above, cooking nasi jimat is a tradition that has been passed on through generations since time of Syarif Hidayatullah (SGJ, 1478) was the sultan of Kasepuhan palace. This ritual has been performed in order to preserve the ancestral tradition, along with the dissemination and the development of Islamic teaching taught by Sunan Gunung Jati in Cirebon. Cooking nasi jimat is a local genius in traditional culinary art since it is not easy to get rice with a natural yellowish color and perfect texture.

Since a long time ago the Sundanese ancestors had venerated the practice of rice-processing, such as the ritual of nyai saripohaci (planting rice), the ritual of seren or taun in Kuningan (harvesting rice). A building where rice (grain) is stored is called leuit (granary) which is separated from the house. But there is also rice storage inside the house called goah, and only women who are allowed to take rice from the storage.

The meaning of the ritual of preparing nasi jimat can be interpreted as following: 1) the recitation of prayers performed in the ritual of preparing nasi jimat reflects the realization of human limitation. Therefore, in doing everything, we should pray that God would bless our intentions. 2) It teaches appreciation for the farmers and food. It teaches us not to waste food, even a grain of rice on our plate. It also teaches the young generation about respect and empathy, especially for the less fortunate. 3) It also functions as a social gathering, especially for the people of Cirebon and Sultan Kaseupuhan XIV and the royal family of the palace, 4) it preserves the culture of gotong royong (mutual cooperation) in commemorating the birth of Prophet Muhammad (muludan) in Cirebon. 5) The veneration of the tradition of preparing nasi jimat is also viewed as an effort in preserving local tradition in Cirebon.

\section{Conclusion}

Based on the discussion above, several conclusions can be drawn as following:

1) The tradition of preparing nasi jimat is a unique way of cooking rice because, unlike the usual way of cooking rice, it uses oil instead of water. The result is yellowish rice with perfect 
grainy texture. The ritual is local genius from the ancestral tradition of Kasepuhan palace Cirebon. Nasi jimat is the main dish cooked and served in the ritual of panjang jimat and has been performed every year since five centuries ago.

2) The tradition of cooking nasi jimat is an attempt to preserve the traditional culture with local wisdom that teach people about peace and respect for each other as taught by Syarif Hidayatillah (SGJ, 1478), the Sultan of Pakungwati kingdom and also a spiritual leader for his people, teaching and disseminating Islam, who believed that Islamic teaching and local tradition could go hand in hand.

3) The veneration of nasi jimat shows that the Kasepuhan palace and the people of Cirebon have a great respect for the traditional heritage of their ancestor and appreciation for food and culinary art as part of their culture. The people of Cirebon believes that the prayers recited in the ritual of preparing nasi jimat would give them divine blessing from God through the veneration nasi jimat and minyak jimat.

\section{References}

Argadukusuma, N. E. (n. d.). Baluarti Keraton Kesepuhan Cirebon.

Dahuri, R., Irianto, B., \& Arovah, E. N. (2004). Budaya Bahari. Jakarta: Perum Percetakan Negara.

Hardjasaputra, S., Haris, T., Yowono, P., Hasyim, R. S., Arovah, E. N., \& Ismarini, A. (2011). Cirebon (Dalam Lima Zaman) Abad ke 15 hingga Pertengahan ke Abad ke 20. Bandung: Dinas Pariwisata dan Kebudayaan Provinsi Jawa Barat.

Hasan, B. (1989). Sekitar Komplek Makam Sunan Gunung Jati dan Sekilas Riwayatnya. Cirebon: Zul Fana.

Kutha, R. N. (2010). Metodologi Penelitian (Kajian Budaya dan Ilmu Sosial Humaniora Pada Umumnya). Yogjakarta: Pustaka Pelajar.

Marcel, D. (2004). Pesan, Tanda dan Makna. (Messages, Signs, and Meaning: A Basic Text Book in Semiotics and CommunicationTheory). Diterjemakan oleh: Setyarini E., Piantari, L.L. Yogjakarta: Jalasutra.

Marsono. (2002). Gunungan dalam Grebeg sebagai Media Dakwa (Analisis Semiotis). Jurnal Dakwa, no 04 tahun III Januari-Juni. Yogjakarta: Fakultas Dakwah IAIN Sunan Kalijaga.

Masinambow, E. K. M., \& Hidayat Rahayu, S. (2001). Semiotik Mengkaji Tanda dalam Artifak. Jakarta: Balai Pustaka.

Nur, N. M. (2000). Bulan Tampa Awan. Cirebon: Pena Press.

Soekanto, S. (1990). Sosiologi. Jakarta: PT Raja Grafindo Persada.

Sugiyono. (2011). Metode Penelitian Kuantitatif Kualitatif Dan R\&D. Bandung: Alfabet.

Sulendraningrat, P.S. (1982). Babad Tanah Sunda Babad Cirebon. 


\section{Copyright Disclaimer}

Copyright for this article is retained by the author(s), with first publication rights granted to the journal.

This is an open-access article distributed under the terms and conditions of the Creative Commons Attribution license (http://creativecommons.org/licenses/by/3.0/). 